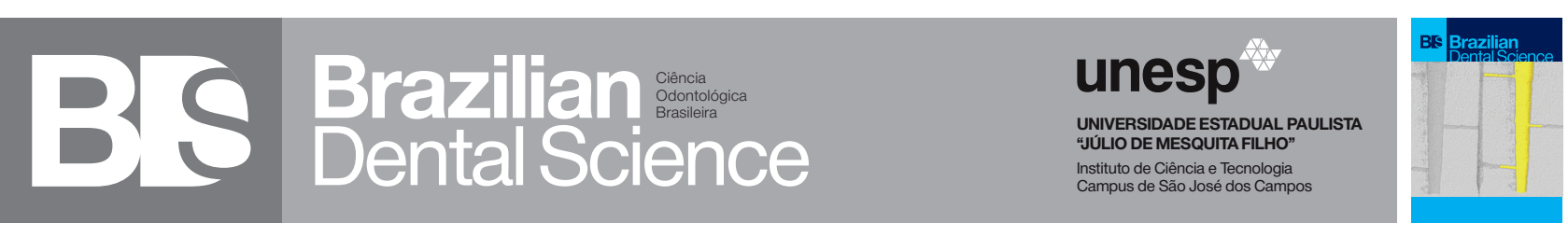

\title{
Effect of thermocycling aging on the flexural strength of feldspathic ceramic
}

Efeito da termociclagem na resistência flexural de uma cerâmica feldspática

Ronaldo Luís Almeida de CARVALHO ${ }^{1}$, Estevão Tomomitsu KIMPARA ${ }^{1}$, Eduardo BRESCIANI ${ }^{2}$, Márcia Carneiro VALERA ${ }^{2}$, Renata Marques de MELO $^{1}$

1 - São Paulo State University (Unesp) - Institute of Science and Technology - Department of Dental Materials and Prosthodontics - São José dos Campos - SP - Brazil.

2 - São Paulo State University (Unesp) - Institute of Science and Technology - Department of Restorative Dentistry - São José dos Campos - SP - Brazil.

\begin{abstract}
Objective: The aim of the study was to evaluate the effect of aging through different thermocycling protocols on the flexural strength of a feldspathic ceramic. Material and Methods: Fifty ceramic bars, Vitablock Mark II (VITA), with dimensions of 18X4X2mm were prepared. The bars were randomly distributed to the groups $(n=10)$, which were defined according to the number of thermal cycles (TCy): G0 - no TCy; G500 - 500 cycles of TCy; G6000 - 6000 TCy; G10000 - 10000 TCy; G15000 - 15000 TCy. After aging, the specimens were subjected to the three point bending test in a universal testing machine (EMIC DL 1000), under $0.5 \mathrm{~mm} / \mathrm{min}$ speed and loading of 50kgf, until catastrophic failure. A sample of each group was evaluated for topographic morphology under Scanning Electron Microscopy. Results: For mechanical testing, the following mean values and standard deviation (MPa) were obtained: G0 (99.78 \pm

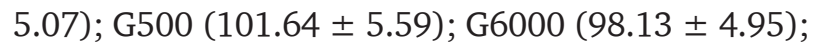
G10000 (91.77 \pm 9.68); G15000 (101.51 \pm 4.22). An analysis of variance by regression equation ( $\mathrm{p}=$ 0.387) was performed, demonstrating a weak and non-significant correlation between flexural strength and number of thermal cycles. Conclusion: It can be concluded that aging in water solely by different numbers of temperature cycles did not influence on the flexural strength of a feldspathic ceramic.
\end{abstract}

\section{KEYWORDS}

Material resistance; Aging; Ceramics.

\section{RESUMO}

Objetivo: O objetivo do estudo foi avaliar o efeito do envelhecimento por meio de diferentes protocolos de ciclos térmicos na resistência à flexão de uma cerâmica feldspática. Material e Métodos: Cinquenta barras de cerâmica, Vitablock Mark II (VITA), com dimensões de $18 \mathrm{X} 4 \mathrm{X} 2 \mathrm{~mm}$ foram preparadas. As barras foram distribuídas aleatoriamente pelos grupos $(\mathrm{n}=10)$, os quais foram definidos de acordo com o número de ciclos térmicos (CT): G0 - nenhum; G500 - $500 \mathrm{CT}$; G6000 - 6000 CT; G10000 - 10000 CT; G15000 15000 CT. Após envelhecimento, as amostras foram submetidas ao ensaio de flexão de três pontos em uma máquina de ensaios universal (EMIC DL 1000), sob a velocidade de $0,5 \mathrm{~mm} / \mathrm{min}$ e célula de carga de 50kgf, até uma falha catastrófica. Uma amostra de cada grupo foi avaliada quanto à morfologia topográfica sob microscopia eletrônica de varredura. Resultados: Para os testes mecânicos, foram obtidos os seguintes valores médios e desvio padrão (MPa): G0 (99,78 \pm 5,07); G500 (101,64 \pm 5,59); G6000 (98,13 \pm 4,95); G10000 (91,77 \pm 9,68); G15000 (101,51 \pm 4,22). Uma análise de variância pela equação de regressão (p $=0,387$ ) foi realizada, o que demonstra uma correlação fraca e não significativa entre a resistência à flexão e do número de ciclos térmicos. Conclusão: Pode-se concluir que o envelhecimento somente em água por diferentes números de ciclos térmicos não influenciou na resistência à flexão de uma cerâmica feldspática.

\section{PALAVRAS-CHAVE}

Resistência de materiais; Envelhecimento; Cerâmicas. 


\section{INTRODUCTION}

In ndirect restorations are exposed to adverse conditions after cementation. Artificial in vitro aging can be performed to simulate in vivo conditions, namely temperature alterations and loading of the oral environment. Mechanical and thermal cycling are among the aging methods that can be used are. These procedures have been used to determine lifetime of restorative materials [1], in which surface cracks or wear contribute to faster deterioration and reduce the fracture resistance [2].

Thermocycling consists of water baths at different temperatures during several cycles. According to Fisher et al. [3], thermal cycles are responsible for aging, reproducing a period of clinical service on restorative materials [3].

The effects of thermal cycling on materials are repeated stresses of contraction and expansion, resulting in propagation of cracks and fractures, loss of retention, formation of cracks at interfaces, and degradation of the restorations [4-9]. In addition to that, water absorption and hydrolytic degradation during the process exert deleterious effect on materials. As an example, Amaral et al. [10] and De Munck et al. [5] showed the importance of water in the degradation of ceramics when the Si-O bonds of the tip of a crack are broken by hydrogen ions leading to the growth of defects. However, these effects are all dependent on aging protocols, such as number of cycles, resting time in each bath and time interval between baths. The consequences of these protocol variations are often contradictory results [10]. It is also difficult to find a consensus with regard to the number of cycles that represents a certain period of clinical service. There are studies indicating 10,000 thermal cycles are equivalent to one year [6] or five years [11-13] of clinical use, or even that 6000 cycles are equivalent to 5 years of use in vivo [3]. Thus, the number of cycles used herein was established based on these previous studies.

In spite of the method constraints, thermocycling is still widely used due to its ability to simulate some of the conditions that occur in vivo. Its use is mainly for the ageing of bonded interfaces, but there is a need to conduct thermocycling in one material alone so that we can better understand its behavior at varying temperatures and moisture. In the present study we chose a feldspathic ceramic and several thermocycling duration times to determine the flexural strength. The null hypothesis was that there were no differences in the flexural strength depending on the thermocycling protocol.

\section{MATERIAL \& METHODS}

Information about the material used in this study is presented in Table 1.

Table 1 - Manufacturer and composition of the material used

\begin{tabular}{|c|c|c|c|}
\hline Material & Manufacturer & Classification & Composition \\
\hline $\begin{array}{l}\text { Vitablock } \\
\text { Mark II }\end{array}$ & $\begin{array}{c}\text { VITA Zahnfabrik } \\
\text { (Bad Säckingen, } \\
\text { Baden-Württem- } \\
\text { berg, Germany) }\end{array}$ & $\begin{array}{c}\text { Feldspathic } \\
\text { Ceramic }\end{array}$ & $\begin{array}{c}\text { Mixture of crys- } \\
\text { talline feldspathic } \\
\text { particles embedded } \\
\text { in glass matrix. SiO2 } \\
\text { (56-64\%); Al203 } \\
\text { (20-23\%); Na20 } \\
(6-9 \%) ; \mathrm{K} 20(6-8 \%) \text {, } \\
\text { CaO (0.3-0.6\%) }\end{array}$ \\
\hline
\end{tabular}

For the fabrication of ceramic Vitablock Mark II bars, the blocks were sectioned into slices with diamond discs in a cutting machine (ISOMET 1000 Buehler Ltd; Lake Bluff, Illinois, USA). A second cut was performed perpendicularly to the slices in order to obtain the bars. At this point the bars were still larger than the desired final dimension.

To standardize the specimens' dimension, bars were polished with $320,400,600$, and 1200 grit sandpaper under water irrigation. The margins were beveled as recommended by the ISO standard for flexure test. Dimension of the final bars was $18 \mathrm{X} 4 \mathrm{X} 2 \mathrm{~mm}$, measured with a digital caliper (Mitutoyo; Suzano, São Paulo, Brasil).

Thermocycling consisted of baths in water at $5{ }^{\circ} \mathrm{C}$ and $55^{\circ} \mathrm{C}$ for 30 seconds, with 2 seconds time interval between baths.

Flexural strength was determined for the 50 experimental units, randomly distributed among different groups (Table 2$)(\mathrm{n}=10)$. 
Table 2 - Group names and description according to the number of thermal cycles

\begin{tabular}{|cc|}
\hline Groups & Description \\
\hline G0 & Vitablock Mark $\|$ without thermocycling \\
\hline G500 & Vitablock Mark $\|+500$ Cycles of thermocycling \\
\hline G6000 & Vitablock Mark $\|+6,000$ Cycles of thermocycling \\
\hline G10000 & Vitablock Mark $\|+10,000$ Cycles of thermocycling \\
\hline G15000 & Vitablock Mark $\|+15,000$ Cycles of thermocycling \\
\hline
\end{tabular}

For the three point bending test, bar was placed in a metal device, being supported on two cylinders (2 $\mathrm{mm}$ in diameter) with a span distance of $16 \mathrm{~mm}$. The load was applied by cylindrical rod (2 $\mathrm{mm}$ in diameter) attached to a universal testing machine (EMIC DL 1000; São José dos Pinhais; Paraná, Brazil), subjecting the specimen to bending $(0.5 \mathrm{~mm} /$ min speed, $50 \mathrm{kgf}$ load cell) until catastrophic failure $[14,15]$.

The mechanical testing procedures were performed immersed in distilled water at $37^{\circ} \mathrm{C}$. For this purpose, a glass container that has received an electric resistance and a thermometer, allowing the device to mechanical testing stay located inside was used.

After mechanical test, a sample from each group was evaluated for topographic morphology in Scanning Electron Microscope (Fei Company Model Inspect-S50; Hillsboro, Oregon, USA), with acceleration speed of 25 $\mathrm{kV}$ and an increase of approximately 1,000X.

To determine the relation between the number of cycles and strength, an analysis of variance was performed using a regression equation.

\section{RESULTS}

Data from the mechanical testing, initially collected in kgf, were converted to MPa values and averaged. The descriptive statistics is presented in graphical form (Figure 1).

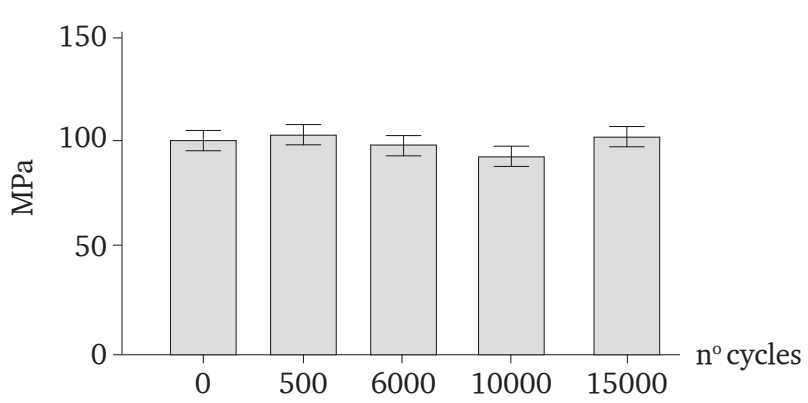

Figure 1 - Chart presenting mean strength values $(\mathrm{MPa})$ and SD according to the number of cycles.

The analysis of variance using a regression equation was performed $(\mathrm{p}=0.387)$, demonstrating a weak and negative (reverse) correlation (Figure 2) between strength and number of thermal cycles.

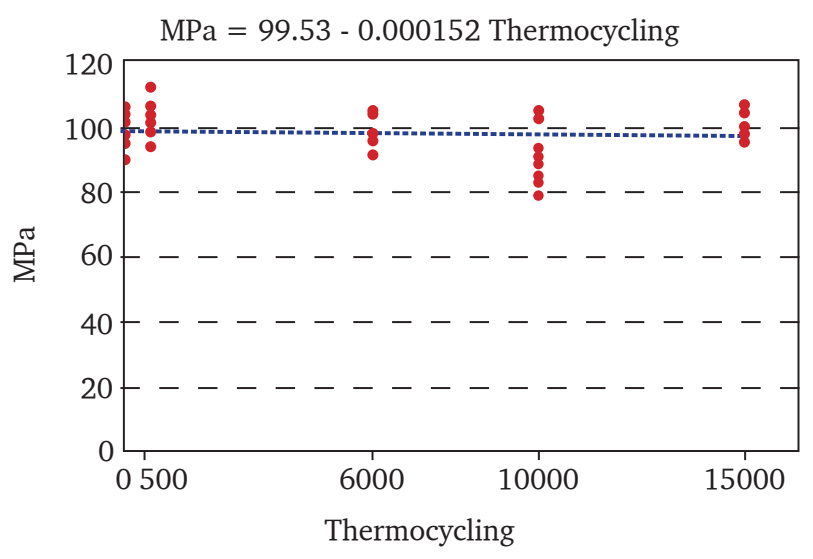

Figure 2 - Graph of regression equation.

To illustrate the topographic surface of ceramic bars after different thermocycling protocols, the surface analysis in Scanning Electron Microscope, with acceleration speed of $25 \mathrm{kV}$ and magnification of $1000 \mathrm{X}$ was performed.

The photomicrographs of feldspathic ceramic (Figure 3) revealed similar topographic patterns for all groups, consisting of a flat surface with the presence of pores and polishing marks (indicated by arrows in Figure 3 ). 

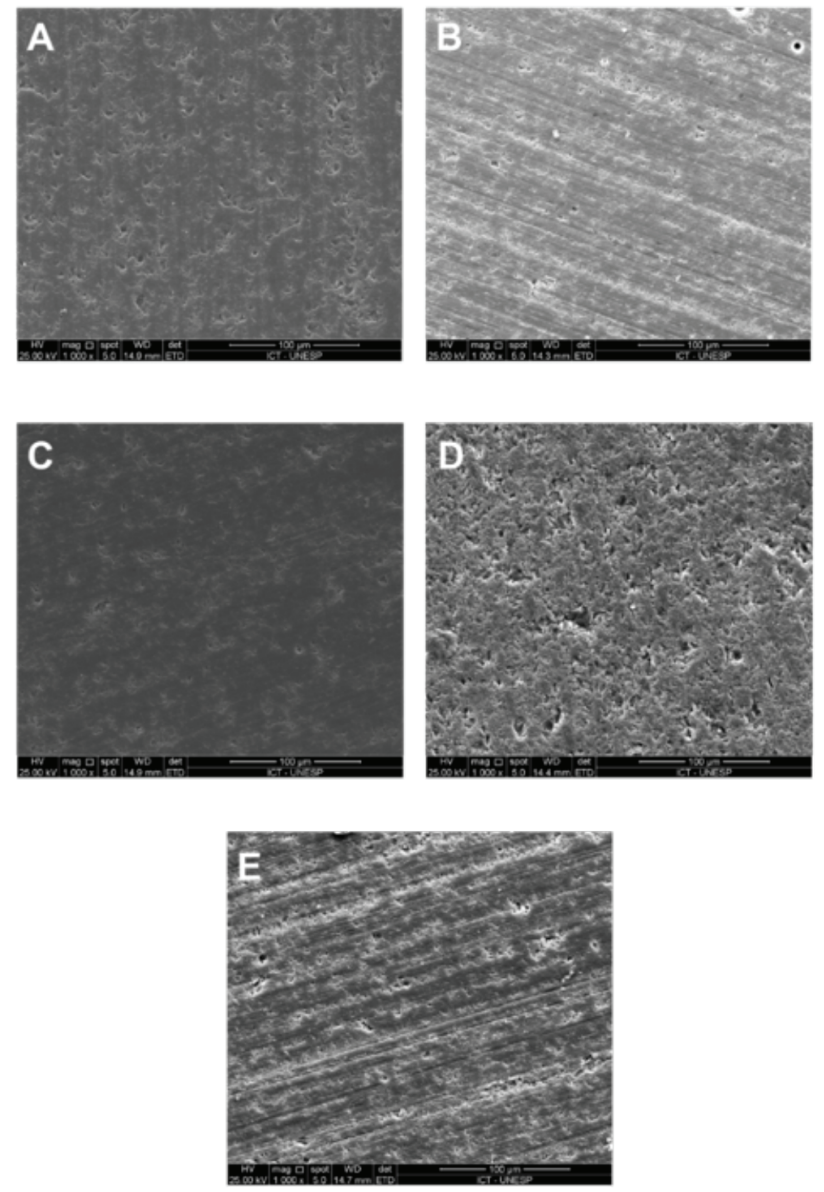

Figure 3 - Photomicrographs of the surfaces of the bars according to the numbers of cycles (A- without thermocycling; B- 500 cycles of thermocycling; C- 6,000 cycles; D- 10,000 cycles; E- 15,000 cycles).

\section{DISCUSSION}

This study showed that varying the number of thermal cycles until 15,000 did not result in statistically significant differences of the flexural strength of a feldspathic ceramic, confirming our anticipated null hypothesis.

With respect to aging protocols, few studies in the literature addressed the intrinsic resistance of ceramics over time. In this study, aging by thermocycling showed that for the feldspathic ceramic, there was not a significant decrease in flexural strength according to the number of thermal cycles performed. These results can be due to the fact that water at different temperatures was used as a single aging factor, as the crack growth is also associated with the presence of low and repetitive loads [16-20].
Moreover, other factors influence the ultimate resistance of ceramic materials including size of the specimens, the test environment, polishing procedure, area of the specimen under tension and test method [21].

From the SEM analysis, it can be observed that there was no difference between the topographical patterns of the photomicrographs for all groups. Although we used with a CADCAM ceramic whose homogeneity (less presence of internal and external defects) is higher than ceramics that are manually applied [22-24], the presence of surface pores certainly affected the final strength of the specimens. This may explain the greater variability of the data in the group of 10,000 cycles.

Recently, de Pinho Barcellos et al.[25] found significant differences on lihtium dissilicate strength depending on the type of ageing. This was probably because this a bi-phase material and the temperature variations led to different thermal contractions of the phases and a decrease in strength. Moreover, according to the authors, the ageing protocol made intra-orally caused more damage to the material than an in-vitro protocol, showing that long lasting thermocycling may not be enough to cause an important decrease in strength.

Therefore, the differences in the mechanical properties of materials due to thermocycling are often a result of thermal mismatches of different phases [26] or different materials combination such as porcelain and zirconia [27]. Also, water and temperature variations in the feldpspathic ceramic used herein were not sufficient to cause topographical changes or a decrease in strength.

Thus, thermocycling aging might be an important condition only when different materials with different thermal behaviors are assessed. For the present study, this type of aging did not have an impact on ceramic strength, no matter the number of thermal cycles.

\section{CONCLUSIONS}

Based on the results of this study it can be concluded that aging in water after several number of thermal cycles had no influence on the flexural strength of a feldspathic ceramic. 


\section{ACKNOWLEDGMENTS}

We are thankful for the Research Laboratory of the Department of Dental Materials and Prosthodontics (School of Dentistry - Institute of Science and Technology - UNESP - Univ Estadual Paulista - São José dos Campos - SP - Brazil) for the use of Scanning Electron Microscope.

\section{REFERENCES}

1. Rosentritt M, Siavikis G, Behr M, Kolbeck C, Handel G. Approach for valuating the significance of laboratory simulation. J Dent. 2008;36(12):1048-53.

2. Rosentritt M, Behr M, Thaller C, Rudolph H, Feilzer A. Fracture performance of computer-aided manufacture zirconia and alloy crowns. Quintessence Int. 2009;40:655-62

3. Fischer J,Zbären C,StawarczykB, Hämmerle CHF. The effect of thermal cycling on metal-ceramic bond strength. J Dent. 2009;37(7):549-53.

4. Anusavice KJ,Kakar K, Ferree N. Which mechanical and physical testing methods are relevant for predicting the clinical performance of ceramic-based dental prostheses? Clin Oral Implants Res. 2007;18(3):218-31.

5. De Munck J, Van LanduytK, Peumans M, Poitevin A, Lambrechts P,Braem M, et al. A critical review of the durability of adhesion to tooth tissue: methods and results. J DentRes. 2005;84:118-32

6. Gale MS, Darvell BW. Thermal cycling procedures for laboratory testing of dental restorations. J Dent. 1999;27(2):89-99.

7. Kelly JR. Clinically relevant approach to failure testing of all-ceramic restorations. JProsthet Dent. 1999;81:652-61.

8. Mazzitelli C, Monticelli F, Toledano M,Ferrari M, Osorio R. Effect of thermalcycling on the bond strength of self-adhesive cements to fiber posts. Clin Oral Investig. 2012; 16:909-915.

9. Thompson JY,Stoner BR, Piascik JR, Smith R. Adhesion/cementation to zirconia and other non-silicate ceramics: where are we now? Dent Mater. 2011 Jan;27(1):71-82. doi: 10.1016/.jdental.2010.10.022.

10. Amaral FLB, Colucci V, Palma-Dibb RG, Corona SAM. Assessment of in vitro methods used to promote adhesive interface degradation: a critical review. J Esthet Restor Dent. 2007;19(6):340-54

11. Behr M, Rosentritt M, Latzel D, Handel G. Fracture resistance of fiberreinforced vs. non-fiber-reinforced composite molar crowns. Clin Oral Invest. 2003;7(3):135-9.

12. Behr M, Rosentritt M, Latzel D, Kreisler T.Comparison of three types of fiberreinforced composite molar crowns on their fracture resistance and marginal adaptation. J Dent. 2001;29 (3):187-96.
13. Lehmann F, Eickemeyer G, Rammelsberg P.Fracture resistance of metal-free composite crowns - Effects of fiber reinforcement, thermal cycling, and cementation technique.JProsthetDent. 2004;92(3):258-64.

14. Della Bona A, Anusavice KJ. Microstructure, composition, and etching topography of dental ceramics. Int J Prosthodont. 2002 Mar-Apr;15(2):159-67.

15. Jin J, Takahashi H, Iwasaki N. Effect of test method on flexural strength of recent dental ceramics. Dent Mater J.2004;23(4):490-6.

16. Anusavice KJP, Shen C, Rawls HR. Phillips materiais dentários. Rio de Janeiro: Guanabara Koogan;2013.

17. Itinoche MK, Oyafuso DK, MiyashitaE, Araújo MAJ, Bottino MA. Avaliação da influência da ciclagem mecânica na resistênciaà flexão de cerâmicas. Cienc Odontol Bras. 2004;7(2):47-54.

18. Oyafuso DK, Ozcan M, Bottino MA, Itinoche MK. Influence of thermal and mechanical cycling on the flexural strength of ceramics with titanium or gold alloy frameworks. Dent Mater.2008;24(3):351-6.

19. StappertCFJ, Chitmongkolsuk S, Silva NRFA, Att W, Strub JR. Effect of mouth-motion fatigue and thermal cycling on the marginal accuracy of partial coverage restorations made of various dental materials. Dent Mater. 2008;24(9):1248-57.

20. Vásquez VZ, Ozcan M, KimparaET. Evaluation of interface characterization and adhesion of glass ceramics to commercially pure titanium and gold alloy after thermal-and mechanical-loading.DentMater.2009;25(2):221-31.

21. Albakry M, Guazzato M, Swain MV. Biaxial flexural strength, elastic moduli, and $\mathrm{x}$-ray diffraction characterization of three pressable all-ceramic materials. J Prosthet Dent. 2003; 89(4):374-380

22. Bindl A, Mörmann WH. Survival rate of mono-ceramic and ceramic-core CAD/CAM - generated anterior crowns over $2-5$ years. Eur J Oral Sci. 2004;112:197-204

23. Kurbad A, Reichel K. Multicolored ceramic blocks as an esthetic solution for anterior restorations. Int JComputDent. 2006;9:69-82.

24. Souza RO, Castilho AA, Fernandes W, Bottino MA, Valandro LF. Durability of microtensile bond to nonetched and etched feldspar ceramic: self-adhesive resin cements vs conventional resin. J Adhes Dent. 2011;13(2):155-62.

25. de Pinho Barcellos AS, Marinho CC, Miranda JS, Amaral M, Shiino MY, Kimpara ET.Effect of fatigue protocols on flexural strength of lithium disilicate bars with clamped-ends. J Mech Behavior of Biomed Mater. 2018;81:173-177.

26. Segerström S, Ruyter IE. Effect of thermal cycling on flexural properties of carbon-graphite fiber-reinforced polymers. Dent Mater.2009 Jul;225(7):845-51.

27. Komine F,Kamio S, Takata H, YagawaS, Taguchi S, Taguchi K, Hashiguchi A, Matsumura H. Effect of framework design on fracture load after thermal cycling and mechanical loading of implant-supported zirconia-based prostheses. Dent Mater J. 2018 Jan 30;37(1):78-86. doi:10.4012/dmj.2017-057.

Ronaldo Luís Almeida de Carvalho (Corresponding address)

Instituto de Ciência e Tecnologia

Curso de odontologia

Av. Engenheiro Francisco José Longo, 777

12245200 São José dos Campos, SP, Brazil.

55-12-39479011

Date submitted: 2018 Feb 14

ronaldo.unesp@outlook.com
Accept submission: 2018 Jul 17 